Modern Asian Studies 37, 2 (2003), pp. 429-46o. (C) 2003 Cambridge University Press DOI: 10.1017/S0026749X03002075 Printed in the United Kingdom

\title{
Four Colonies and a Kingdom: A Comparison of Fiscal, Trade and Exchange Rate Policies in South East Asia in the I930s
}

\author{
ANNE BOOTH \\ School of Oriental and African Studies \\ University of London
}

\section{Introduction}

In the latter part of the 1990s, several of the major economies in South East Asia underwent one of the worst economic crises in living memory. It is thus not surprising that economic historians with an interest in the region are re-examining the experience of the 1930 . One crucial difference between the crisis of the late 1990 s and that of the early 1930 s is that the latter was preceded, and in large measure caused, by problems in the world economy. When the industrial world fell into a severe economic depression in the early 1930s, most parts of Asia were affected, mainly through falling export receipts which in turn affected colonial budgets. A second difference was that most parts of South East Asia in the 1930s were still under colonial rule, and had little autonomy in framing or implementing economic policy. Only Thailand remained nominally independent, but even there the influence of foreign, especially British, economic advisers was considerable. Given the very different economic interests which the colonial powers (Dutch, French, American and British) had in their South East Asian colonies, and given the widely differing nature of the economic links between colony and metropole, it was to be expected that the impact of the 1930s slump, and the policy

\footnotetext{
${ }^{1}$ Versions of this paper have been presented at the International Association of Historians of Asia (IAHA) conference in Jakarta in 1998 and the European Association of South East Asian Studies (EUROSEAS) conference in London in 2001. I am grateful to conference participants, and also to Gregg Huff of the University of Glasgow, for helpful comments. In addition I am grateful to Jean-Pascal Bassino of Paul Valery University, Vauban, for making available to me his estimates of GDP in North and South Vietnam for the inter-war years.
}

oo26-749X/o3/\$7.50+\$0.10 
responses which it provoked, would vary. This indeed turned out to be the case.

This paper has three purposes. The first is to examine the impact of the 1930s depression on output and living standards in four South East Asian colonies: Burma, Indochina, the Netherlands Indies and the Philippines, and to compare the impact on these colonies with the Kingdom of Thailand. Second, the paper examines the policy responses to the world crisis adopted by these five regimes, paying particular attention to budgetary, trade and exchange rate policies. Third, the paper asks what difference alternative policies would have made to the impact of the world crisis on these economies and also examines the longer term effects on economic policymaking after 1945 .

\section{The Impact of the 1930s Depression on Output and Living Standards}

The first three decades of the twentieth century witnessed a rapid growth and diversification of exports from all parts of South East Asia. These exports were predominantly agricultural although tin and petroleum products were also important, especially in the Netherlands Indies. In volume terms, exports and imports grew rapidly from the early 1900 s through to 1930 and although most countries experienced some decline in the early part of the 1930s, recovery took place quite quickly and export volumes were all higher in the Philippines, the Netherlands Indies, Burma, French Indochina and Thailand in 1938 than they had been in 1925 (Table 1). Per capita exports in nominal US dollars were at least as high everywhere in the region in $1934-3^{8}$ as they had been in 1909-13 and several countries (Thailand, the Philippines, Burma and Indo-China) achieved significant increases (Booth 2000: Table 14.1). By the second part of the 1920 , the ratio of exports to GDP appears to have been well over 20 per cent everywhere in South East Asia, and indeed much higher in Burma and the Philippines. Although there was some decline in this ratio in Vietnam and the Netherlands Indies in the early 1930s, it increased again after 1935, although it did not recover 1926 levels in either country (Table 2). Import volumes also began to recover in most parts of the region after 1935, and with the exception of Burma had surpassed 1925 levels by 1938 (Table $3)$. 
TABLE 1

Export Volume Indices $(1925=100)$

\begin{tabular}{lccccc}
\hline Year & NEI & Thailand & Philippines & FIC & Burma \\
\hline 1925 & 100 & 100 & 100 & 100 & 100 \\
1929 & 133 & 97 & 138 & 107 & 105 \\
1930 & 128 & 88 & 129 & 88 & 83 \\
1931 & 114 & 103 & 122 & 77 & 84 \\
1932 & 118 & 117 & 125 & 87 & 115 \\
1933 & 111 & 121 & 146 & 101 & 125 \\
1934 & 106 & 145 & 170 & 115 & 145 \\
1935 & 108 & 114 & 133 & 129 & 154 \\
1936 & 112 & 131 & 152 & 142 & 134 \\
1937 & 128 & 112 & 151 & 147 & 120 \\
1938 & 118 & 131 & 165 & 137 & 120 \\
1939 & 127 & n.a. & n.a. & 163 & 130 \\
\hline
\end{tabular}

Sources: NEI: Van Ark (1986); FIC: Service de la statistique générale (1947); Thailand and the Philippines: Birnberg and Resnick (1975); Burma: export data from National Planning Commission (1960), Statistical Appendix, deflated by unit value index of exports given in Aye Hlaing (1964: 146).

TABLE 2

Trends in the Export/GDP Ratio I9OI-1938 (percentage)

\begin{tabular}{lccccc}
\hline Year & NEI & Thailand & Philippines & Vietnam & Burma \\
\hline 1901 & 12 & n.a. & $28(1902)$ & 19 & 30 \\
1906 & 16 & n.a. & n.a. & 16 & $4^{2}$ \\
1911 & 17 & $17(1913)$ & n.a. & 18 & $4^{1}$ \\
1916 & 22 & n.a. & $32(1918)$ & 18 & 35 \\
1921 & 16 & n.a. & n.a. & 20 & 47 \\
1926 & 26 & $22(1929)$ & n.a. & 25 & $3^{6}$ \\
1931 & 16 & n.a. & n.a. & 14 & $4^{\mathrm{O}}$ \\
1936 & 17 & n.a. & n.a. & 21 & $5^{\mathrm{O}}$ \\
1938 & 17 & 25 & 34 & 22 & $4^{8}$ \\
\hline
\end{tabular}

Sources: NEI: export data from Korthals Altes (1991), Table $2 B$; nominal GDP data given to the author by Pierre van der Eng; Thailand Sompop (1989: 251); Ingram (1971: 333-5); Philippines: Hooley (1968); Vietnam: export data from Bassino and Huang (2000), Table 1; nominal GDP data given to the author by Jean-Pascal Bassino; Burma: Aye Hlaing (1964: 111 ).

These figures may suggest that all the colonial powers in South East Asia were pursuing broadly similar fiscal policies, and foreign trade and exchange rate policies over the first four decades of the century, and that in most cases these policies were successful in promoting rapid export growth and in shielding the colonies from the worst effects of the world crisis of the early 1930s. In fact this was far from being the case. First, there were important differences in different parts of the region in the magnitude of the contraction of 
TABLE 3

Import Volume Index $(1925=I O O)$

\begin{tabular}{lrcccr}
\hline Year & NEI & Thailand & Philippines & FIC & Burma \\
\hline 1925 & 100 & 100 & 100 & 100 & 100 \\
1929 & 147 & 130 & 141 & 149 & 111 \\
1930 & 130 & 115 & 123 & 130 & 102 \\
1931 & 109 & 88 & 120 & 106 & 89 \\
1932 & 91 & 92 & 110 & 91 & 88 \\
1933 & 85 & 96 & 102 & 90 & 82 \\
1934 & 79 & 107 & 113 & 104 & 94 \\
1935 & 77 & 124 & 116 & 108 & 98 \\
1936 & 78 & 130 & 132 & 113 & 104 \\
1937 & 106 & 113 & 136 & 137 & 110 \\
1938 & 106 & 136 & 157 & 139 & 93 \\
1939 & 112 & n.a. & n.a. & 162 & 121 \\
\hline
\end{tabular}

Sources: NEI: Import data from Korthals Altes (1991), Table ${ }_{3} B$. deflated by the import volume index in Korthals Altes (1994), Appendix A; FIC: Service de la statistique générale (1947); Thailand and the Philippines: Birnberg and Resnick (1975); Burma: import data from National Planning Commission (1960) Statistical Appendix, deflated by unit value index of imports given in Aye Hlaing (1964: 146).

export volume and in the pace of recovery. Second, there were quite striking differences in contraction and subsequent expansion of import volumes. Third, the evidence in Table 2 suggests that trends in exports did not reflect the full impact of the world depression on output in South East Asia. This can be seen from the data on real growth of per capita national product between 1900 and 1940. Thailand, the Philippines, the Netherlands Indies, South Vietnam and Burma all experienced some increase in per capita national product in the first two decades of the century; and in Burma, South Vietnam and Indonesia this growth was sustained until the late 1920s (Table 4). North Vietnam's per capita GDP hardly grew between 1900 and 1913, but growth accelerated between 1913 and 1929. In Burma per capita net national product was substantially higher in 1931/2 than it had been in 1926/7. But all countries except Thailand appear to have experienced a decline in real output per capita for most of the 1930s, although there is clear evidence of some recovery in both Indonesia and South Vietnam in the second part of the decade. But only in North Vietnam was per capita GDP higher in 1938 than in any year since 1900 .

In the case of Thailand, the apparent failure of the economic turbulence of the 193 os to have much impact on per capita output owed more to the structure of the economy than to economic policy. In fact, as will be shown below, fiscal policy was more 
TABLE 4

Index of Growth of Real Per Capita GDP for Selected Years between I9oo and I938 $(I 938=$ IOO)

\begin{tabular}{|c|c|c|c|c|c|c|}
\hline \multirow[t]{2}{*}{ Year } & \multirow[t]{2}{*}{ Burma } & \multirow[t]{2}{*}{ Indonesia } & \multirow[t]{2}{*}{ Philippines } & \multirow[t]{2}{*}{ Thailand } & \multicolumn{2}{|c|}{ Vietnam } \\
\hline & & & & & North & South \\
\hline 1900 & & 70 & & 89 & 82 & 76 \\
\hline 1901 & 95 & 68 & & & 85 & 80 \\
\hline 1902 & & 66 & 72 & & 85 & 89 \\
\hline 1911 & $8_{3}$ & $8_{3}$ & & & $8_{3}$ & 91 \\
\hline 1913 & & 90 & & 102 & 81 & 99 \\
\hline 1916 & 112 & 85 & & & 78 & 91 \\
\hline 1918 & & 86 & 107 & & 80 & 90 \\
\hline 1926 & 110 & 102 & & & 89 & 101 \\
\hline 1928 & & 109 & 105 & & 90 & 97 \\
\hline 1929 & & 109 & & $9^{6}$ & $9^{6}$ & 91 \\
\hline $193^{1}$ & 122 & 101 & & & 84 & 79 \\
\hline $193^{6}$ & 114 & 95 & & & 96 & 95 \\
\hline $193^{8}$ & 100 & 100 & 100 & 100 & 100 & 100 \\
\hline
\end{tabular}

Note: Data for Burma refer to net domestic product.

Sources: Burma: Aye Hlaing (1965: 289); NEI: Van der Eng (1992); Thailand: Sompop (1989: 251); Philippines: Hooley (1968); Vietnam: Bassino, unpublished estimates quoted in Bassino (2001).

contractory in Thailand in the early part of the 1930 s than in any of the four colonies. Thus it can be argued that economic policy probably aggravated the effects of the world crisis on the domestic economy. Ingram (1971: 162) has suggested that the lack of involvement of the majority of the population in Thailand in the cash economy, together with low supply elasticities for staples such as rice and the low level of development of the non-agricultural economy all meant that most Thais were little affected by the effects of the depression. Sompop (1989: 70) argues that the entire period from 1910 to $195^{\circ}$ was characterized by slow growth in the export economy, and there is little evidence that the decade of the 1930 s was especially bad. In fact, value added in the agricultural sector grew quite rapidly between 1929 and 1938, and accounted for almost half of total growth in GDP (Table 5).

In neighbouring Burma by contrast, the NDP estimates compiled by Aye Hlaing (1965) indicate that there was a significant decline in per capita terms over the 193 os (Table 4). This seems unlikely to be solely due to the export sector, as the export volume decline was no more serious than in Thailand, and the recovery about as 
TABLE 5

Accounting for Output Change: The Role of the Agricultural and Non-agricultural Sectors

\begin{tabular}{lcccc}
\hline & \multicolumn{4}{c}{$\%$ of the Increase/Decrease in GDP by Sector } \\
\cline { 2 - 5 } & $\begin{array}{c}\text { Indonesia } \\
1928-38\end{array}$ & $\begin{array}{c}\text { Thailand } \\
1929-38\end{array}$ & $\begin{array}{c}\text { Philippines } \\
1928-38\end{array}$ & $\begin{array}{r}\text { Burma } \\
1931 / 2 \\
1938 / 9\end{array}$ \\
\hline Agriculture & 34 & 46 & 12 & -123 \\
Non-agriculture & 66 & 54 & 88 & 23 \\
Total & 100 & 100 & 100 & 100 \\
Annual average percentage growth in value added: & & \\
GDP & 0.9 & 2.9 & 1.9 & -1.4 \\
Agriculture & 0.9 & 3.0 & 0.5 & -3.1 \\
\hline
\end{tabular}

Sources: As for Table 4; note that the data for Burma refer to net domestic product.

rapid (Table 1). Aye Hlaing's estimates suggest that all the decline in domestic product over the 1930 s was due to the agricultural sector; value added in the non-agricultural sectors, including mining, grew over the decade (Table 5). The key task is to explain this decline, and relate it to fluctuations in both domestic and international demand.

In both the Netherlands Indies and the Philippines, there had been a rapid increase in export volume in the latter part of the 1920s; in the case of the Netherlands Indies export volume had not recovered its 1929 level by 1940 (Table 1). The Philippine export economy proved more robust for reasons which will be discussed below. But as Hooley (1968: 7-9) has shown, most of the output growth in the Philippine economy after 1918 came from the non-agricultural sectors; foodcrop agriculture in particular was characterized by falling yields and stagnating technologies. Only $12 \%$ of total growth in value added between 1928 and 1939 came from the agricultural sector, and in per capita terms agricultural value added declined. In the Netherlands Indies, around one-third of the growth in value added which occurred over the 1930 s came from the agricultural sector, which was considerably more than in the Philippines but less than in Thailand (Table 5).

The effect of the world crisis of the 1930 os on living standards in South East Asia has been much debated. Brown (1986: 9961000) uses data from two rural surveys carried out in Thailand in 1930-31 and 1933-34 to argue that there was no clear evidence of falling consumption. But given the output data assembled 
by Sompop (1989: 251) this is hardly surprising; if per capita output rose slightly over the decade, we would not expect a sharp decline in consumer expenditures. ${ }^{2}$ In other parts of South East Asia the evidence is more contentious, although there is certainly evidence of hardship in those regions where large numbers of wage labourers lost their jobs (for example the sugar-growing regions of Java) or where markets for cashcrop sales contracted because of international commodity agreements. Huff (2001), using an entitlements approach, has argued that in British Malaya, those workers who relied largely on non-food agriculture and mining for their incomes suffered considerable distress as commodity prices fell. Many of these people had little or no land to fall back on. In some cases they drifted into the urban informal sector in Singapore, where they eked out a miserable living as traders or coolies. Huff presents evidence that the living standards of the poorer groups in Singapore, who did not have fixed money incomes, fell during the crisis. This was almost certainly true in other cities in South East Asia, especially in regions such as Java and Northern Vietnam where rural population pressures were high.

By contrast, in land abundant areas where cultivators never lacked the land to grow food, severe hardship was rare. Sompop (2000: 193-4) argues that the smaller, subsistence oriented farmers in Thailand were unaffected by the fall in rice prices, because they sold only a very small part of their production and were not reliant on imported necessities. Similarly Norlund (2000: 209) has argued that in Vietnam, small farmers and tenants who kept their land were not adversely affected, and indeed may have benefited from lower rice prices. Norlund argues that it was the more commercial, and more indebted farmers in the south who were most severely hit by the crisis. Similarly Brown (1999: 154) points out that it was the indebted farmers in the Irrawaddy delta of Burma who felt the effects of the crisis the most; in many cases they lost their land. In Java, millions of people were hurt by the direct and indirect effects of the contraction of the sugar industry. There is also evidence of growing income disparities, especially where nominal wages did not fall as fast as prices. To

\footnotetext{
${ }^{2}$ It should be noted that some senior Thai officials did argue that the effect of falling rice prices on rural incomes in some regions was severe; see for example the report by Prince Burachat translated and published in Chatthip et al. (1981: 198222).
} 
the extent that some economic groups actually increased their incomes while others experienced a decline, it is hazardous to use trends in averages (such as average rice production per capita) to make claims about trends in living standards.

\section{Policy Responses: Budgetary Policies}

By the 1920s, all the economies of South East Asia had developed significant export sectors, relative to national output (Table 2). This export dependence had important budgetary implications. Taxes levied on exports and imports accounted for around 30\% of total budgetary revenues in both Burma and Vietnam by the late 1920s; although the ratio was lower elsewhere (at least in part because of the importance of revenues from government monopolies), large export and import companies accounted for a considerable part of government revenues from corporate income taxes. Thus when prices of key export staples began to fall, government revenues were affected in several ways. Export tax revenues fell with falling world prices, and as import volume contracted so did revenues from import taxes. The decline in both the volume and value of exports and imports also affected corporate profits and thus revenues from income taxes.

It might have been expected that the colonial governments in South East Asia would all have pursued conservative budget policies after 1929, and cut expenditures as revenues fell. In fact in the Philippines, Vietnam and the Netherlands Indies this did not happen. After 1930, budgetary expenditures increased relative to revenues; in both Vietnam and the Netherlands Indies, expenditures exceeded revenues by around $50 \%$ in 1932 (Table 6). Budget deficits of this magnitude were not viewed as sustainable and after 1933 they were reduced in both colonies although in the Netherlands Indies, budgetary expenditures exceeded revenues for the rest of the decade. After 1935, budget surpluses were achieved in both Vietnam and the Philippines. In Burma, government revenues exceeded expenditures by a wide margin and this was only slightly reduced as the depression worsened. The reason for these surpluses was that Burma was expected to make a significant contribution to the budget of British India. Needless to say, this 'fiscal drain' attracted criticism from Burmese economists after independence (Aye Hlaing 1965: Chapter 3). It was brought to an end in the 
TABLE 6

Budgetary Expenditures and Trade Taxes as a Percentage of Budgetary Revenues, I929-39

\begin{tabular}{lccccr}
\hline Year & Burma & Vietnam $^{\text {a }}$ & $\begin{array}{c}\text { Netherlands } \\
\text { Indies }\end{array}$ & Philippines & Thailand \\
\hline \multicolumn{5}{l}{ Budgetary expenditures as a percentage } & of budgetary revenues \\
1929 & 57.3 & 107.6 & 101.9 & 88.9 & 99.1 \\
1930 & 58.9 & 110.3 & 119.2 & 106.5 & 103.8 \\
1931 & 64.3 & 118.2 & 126.0 & 110.7 & 112.8 \\
1932 & 59.7 & 154.6 & 148.3 & 106.7 & 92.6 \\
1933 & 61.9 & 128.5 & 147.1 & 101.4 & 92.5 \\
1934 & 56.2 & 112.2 & $135 \cdot 3$ & 89.9 & 84.9 \\
1935 & 54.6 & 102.3 & 118.7 & 91.7 & 97.3 \\
1936 & n.a. & 89.3 & 114.0 & 89.2 & 92.5 \\
1937 & 92.1 & 76.4 & 107.7 & 50.0 & 114.7 \\
1938 & 93.8 & 86.8 & 111.7 & 106.0 & 112.4 \\
1939 & 90.0 & 82.9 & 119.4 & 96.6 & 124.5 \\
Trade taxes as a percentage of total revenues & & \\
1927 & 33.5 & 30.0 & 12.6 & 24.1 & 17.9 \\
1938 & 26.4 & 31.0 & 16.1 & 19.0 & 30.5 \\
\hline
\end{tabular}

${ }^{a}$ Refers to central government revenues and expenditures only.

Sources: Burma: National Planning Commission (1960), Statistical Appendix; Andrus (1948: Tables 37 and 38); Vietnam: Bassino (2000), Tables 1 and 2; Netherlands Indies: Creutzberg (1976); Philippines: Bureau of Census and Statistics (1941), Chapter XII; Thailand: Ingram (1971: 328-29, Table XV).

latter part of the decade when Burma was formally separated from the rest of India, although in the three fiscal years after April 1, 1937 the Government of Burma was still running a budgetary surplus (Andrus 1948: Tables 37 and 38 ).

Ironically the economy which experienced the most severe fiscal contraction in the early part of the 193 os was Thailand, which was nominally independent (Table 6). In fact as several observers pointed out, the Thai authorities had always prided themselves on their fiscal conservatism (Ingram 1971: 196-202; Sompop 1989: 182-3; Schwulst 1931: 48). The influence of British financial advisers, combined with the fear of the Thai elite that fiscal profligacy would have led to more overt foreign control of the economy, are the reasons most often advanced for the Thai fiscal stance. The extreme fiscal conservatism meant that the government was reluctant to borrow even to finance capital works. The result was that by the early 1930 , the share of the Thai budget being spent on public works was lower than in any of the South East Asian colonies, while the share on 
TABLE 7

Budgetary Revenues and Expenditures per Capita, I929, I934 and I938

\begin{tabular}{|c|c|c|c|c|c|}
\hline Year & Burma & Vietnam $^{\mathrm{a}}$ & $\begin{array}{l}\text { Netherlands } \\
\text { Indies }\end{array}$ & Philippines & Thailand \\
\hline \multicolumn{6}{|c|}{ Budgetary revenues (US dollars per capita) } \\
\hline 1929 & 6.44 & $2.5^{2}$ & 5.14 & 3.63 & 4.15 \\
\hline 1934 & 6.19 & 2.27 & $3 \cdot 5^{6}$ & 2.73 & 3.16 \\
\hline $193^{8}$ & $3 \cdot 73$ & $1.4^{6}$ & $3 \cdot 72$ & $4 \cdot 19$ & $3 \cdot 5^{\mathrm{O}}$ \\
\hline \multicolumn{6}{|c|}{ Budgetary expenditures (US dollars per capita) } \\
\hline 1929 & 3.69 & 2.92 & 5.24 & 3.22 & 4.11 \\
\hline 1934 & $3 \cdot 48$ & 2.49 & 4.82 & 2.45 & 2.68 \\
\hline 1938 & $3 \cdot 5^{\mathrm{O}}$ & 1.40 & 4.15 & $4 \cdot 45$ & 3.93 \\
\hline
\end{tabular}

${ }^{a}$ Figures for Vietnam refer to both central and local government revenues and expenditures.

Sources: Budget data: Burma: National Planning Commission (1960), Statistical Appendix; Andrus (1948: Tables 37 and 38); Vietnam: Bassino (2000), Tables 1 to 3; Netherlands Indies: Creutzberg (1976); Philippines: Bureau of Census and Statistics (1941), Chapter XII; Thailand: Ingram (1971: 328-29, Table XV).

Population data from Hooley (1968), Ingram (1971: 46), Banens (200o), Central Bureau of Statistics (1947: 6); Andrus (1948: 23).

Exchange rates: van der Eng (1993); van Laanen (1980); Service de la statistique générale (1947).

general administration was higher (Schwulst 1931). ${ }^{3}$ The conservative approach appears to have intensified after the military coup of 1932 which brought the absolute monarchy to an end. Between 1932 and 1936, budgetary expenditures were kept well below revenues, which had begun to grow again in nominal terms after reaching a trough in 1932 (Ingram 1971: 329). Only after 1936 did expenditures overtake revenues, at least partly because of the growth of spending on capital works.

By the end of the 1930 s there was in fact considerable convergence in both budgetary revenues per capita and budgetary expenditures per capita among the five economies considered here (Table 7). The extreme outlier was Vietnam where by 1938 , budgetary expenditures were only $35 \%$ of the average of the other four. The reasons for this are not entirely obvious. Schwulst (1931: 42-4) drew attention to the very low expenditures in 1930 in Vietnam compared to other

3 The exception was Burma which Schwulst did not consider. According to Aye Hlaing (1965: Table 22), in the late 1920s, about one-third of budgetary expenditures was devoted to social services such as health and education, and public works, while two-thirds went to general administration. This can be contrasted with the Philippines where, according to Schwulst, over half of all budgetary expenditures went on health, education and public works. 
parts of South East Asia, and explained it in terms of low allocations to social services. ${ }^{4}$ It is striking that the decline in both per capita revenues and expenditures in Vietnam over the 1930s was much more rapid than in any other part of South East Asia, which would suggest that a failure of revenue policy, combined with pressures to eliminate the large deficits of the early part of the decade, led to Vietnam's anomalous position in 1938.

\section{Policy Responses: Trade and Exchange Rate Policies}

The Evolution of Trade and Exchange Rate Regimes in South East Asia. One of the main considerations which governed fiscal policy everywhere in the region over the 1930 s was the need to maintain exchange rates in terms of the metropolitan currency. In 1930, when the Indochina piastre was given an exact value in gold equal to ten times that of the French franc, all the currencies in South East Asia were briefly on the gold standard. ${ }^{5}$ Over the early part of the 1930s, the various South East Asian colonies followed their metropolitan masters in deciding to abandon, or stay with, the gold standard; the British colonies left with sterling in September 1931, while the Netherlands Indies stayed on gold with the Netherlands until 1936. Thailand stayed on the gold standard for several months after sterling was devalued while an intense policy debate raged about appropriate policy responses to the deepening world crisis (Batson 1984: Chapter VII; see also Vichitvong 1978). Finally, in May 1932, the Thai cabinet agreed to relink the baht to sterling at the rate which prevailed before sterling went off gold, and this link was maintained until 1942. ${ }^{6}$ The Philippines had been pegged to the US dollar since the Philippine Gold Standard Act of 1903. The system broke down in 1918, and in 1922 a separate Gold Standard Fund and Treasury Certificate Fund was established. Thereafter, the overwhelming

${ }^{4}$ It should be noted that the data in Table 7 include the provincial budgets for Tonkin, Annan and Cochinchina as well as the central government budget. In this sense the data for Vietnam may actually be overstated compared with the other countries which refer to central government revenues and expenditures only.

${ }^{5}$ See Bassino and Nakagawa (2000: 11-13) for a discussion of the debate surrounding the decision to put the piastre on the gold standard.

${ }^{6}$ The British financial adviser, Hall-Patch, argued that Thailand should stay on the gold standard while his influential predecessor, Sir Edward Cook (by then in Cairo) advised that the baht should remain pegged to sterling (Batson 1984: 219). Cook's advice was eventually adopted. 
priority of successive Philippine administrations was to maintain the peg to the US dollar, rather than to maintain a fixed parity with gold, and the peso went off the gold standard with the dollar in 1933 . Parity with the US dollar was maintained until 1941, although critics argued that the cost was 'excessive' levels of reserves held in US banks (Jenkins 1954: 112).

There were also considerable differences across South East Asia in trade regimes and structures of protection. Acts passed by the US congress in 1909 established free trade between the USA and the Philippines, although some quantitative restrictions remained on Philippine exports to the USA (Espino 1934: 8). These were largely removed by the Underwood Tariff Act of 1913, which permitted all Philippine products containing no more than $20 \%$ by value of foreign materials to enter the USA duty free. Essentially the Underwood Act remained in force until the mid-1930s when the Philippines was granted self-government. Although there were critics of what was in effect a Philippine-USA customs union in both the USA and the Philippines, powerful lobbies in both countries benefited from it and developed a strong interest in maintaining it. By the end of the first world war almost two-thirds of Philippine imports originated from the USA, and in 1929-33 the American share of Philippine imports was four times its share of world exports (Table 8). An even higher proportion of Philippine exports went to the USA. This reliance led some Philippinos to argue for political independence on the grounds that they must regain tariff autonomy in order to foster their own industries, although agricultural interests, especially the sugar growers, were far from enthusiastic about independence as they realized they would lose preferential access to the American market. ${ }^{7}$

Until 1928 trade between metropolitan France and the French colonies was governed by tariff laws which provided extensive protection for French products in colonial markets. Indeed, leading French politicians made little secret of the fact that a key role of colonies was to provide protected markets for French industries. ${ }^{8}$ But the

\footnotetext{
${ }^{7}$ An extensive discussion of USA-Philippine trade is given in United States Tariff Commission (1937); Espino (1934) discusses the arguments in favour of tariff autonomy. Friend (1963) examines the complex negotiations over sugar quotas which preceded independence, and Friend (1965: 116-21) analyses the economic interests of the groups opposing independence. See also Corpuz (1997: 251-62) for a discussion of the negotiations leading up to the formation of the transitional Commonwealth government in November 1935 .

${ }^{8}$ See Marseille (1984: 50) who quotes Jules Ferry's dictum that 'la politique coloniale est fille de la politique industrielle'. Meredith (1996: 34 ) has argued that by the inter-war period, Britain too 'valued its tropical colonies more as a market than as a source of supply of primary produce'.
} 
TABLE 8

Metropolitan Shares of World Export Trade and Colonial Import Trade, I929-33

\begin{tabular}{lccc}
\hline & $\begin{array}{c}\text { Metropolitan Share } \\
\text { of Imports (\%) }\end{array}$ & $\begin{array}{c}\text { Metropolitan Share } \\
\text { of World Exports (\%) }\end{array}$ & Ratio \\
\hline NEI & 16.95 & 2.57 & 7.8 \\
Philippines & 63.81 & 13.75 & 4.6 \\
Indochina $_{\text {Burma }^{a}}$ & 55.27 & 6.15 & $9 \cdot 0$ \\
Thailand $^{\mathrm{b}}$ & $22.7(45 \cdot 4)$ & $10.28(3.25)$ & 2.2 \\
& 15.5 & 10.28 & 1.5 \\
& Japanese Share & Japanese Share & Ratio \\
NEI Imports (\%) & of World Exports (\%) & \\
Philippines & 14.34 & 2.86 & 5.0 \\
Indochina & 9.24 & 2.86 & 3.2 \\
Burma & 2.76 & 2.86 & 1.0 \\
Thailand & 9.3 & 2.86 & 3.3 \\
\hline
\end{tabular}

${ }^{a}$ Figures in parentheses are for the rest of British India.

${ }^{\mathrm{b}}$ Metropolitan power is the United Kingdom.

Source: Thailand: Swan (1988: 76); FIC: Service de la statistique générale (1947); Philippines: Bureau of Census and Statistics (1941); Netherlands Indies: Korthals Altes (1991); Burma: National Planning Commission (1960), Statistical Appendix. Data on metropolitan countries' share of world exports from Clark (1936), pp. $62-3$.

tariff provisions were not reciprocal in that colonial products did not automatically enjoy duty-free entry into France. This inequity gave rise to great resentment in Indochina, and was finally removed in 1928 when a regime of reciprocal free trade was established within the French Empire. As a result of this protectionism, Indochina conducted very little of its trade with neighbouring countries, while the share of metropolitan France in Indochina's imports was nine times France's share of world exports in 1929-33 (Table 8).

The discriminatory trade regimes imposed by both the USA and France on their South East Asian colonies can be contrasted with the more liberal approach of the Dutch. Not only was there virtually no tariff or non-tariff discrimination against imports from any source after the reforms of the 1860 s and 1870 , but there was also an open capital account facilitating the inflow of capital and the repatriation of profits. Although both specific and ad valorem import taxes were levied, both Dutch and foreign commentators emphasized that tariffs were purely for revenue purposes, and the idea of protection was totally foreign (Paulus 1909: 124; Fowler 1923: 399; Kuitenbrouwer 1991: 67). But in spite of the apparently non-discriminatory trade regime, the Netherlands continued to account for a much greater share of imports into the Indies than its share of total world 
trade would have justified. Import enforcement ratios certainly fell between 1880 and 1900 but by 1929-33, the Dutch share of imports into the Netherlands Indies was still almost eight times its share of world exports (Table 8). It is likely that various forms of subtle discrimination against British and other importers persisted after 1870 through the dominance of Dutch trading houses in the exportimport sector, and of course through a Dutch commercial and legal system which would have advantaged Dutch merchants.

The situation in Burma was complicated by the fact that Burma was just a small part of Britain's vast colonial possessions in the Indian sub-continent, and until the latter part of the 1930 s had no autonomy in economic, or indeed other, matters. The constitutional reforms of the early 1920 s had accorded India considerable autonomy in setting tariffs, and during the 1920 s some tariff protection was accorded Indian producers of iron and steel products and textiles (National Planning Commission 1960: 84ff). But these tariffs had no protective function in Burma which did not possess such industries; their only effect was to increase prices of imported textile and steel products. After the Ottawa Agreement of 1932 India shifted to a system of tariff preferences for products from other parts of the British Empire, and over the next two years very high tariffs were levied on imports from countries outside the imperial system, most notably textile products from Japan (Chaudhuri 1983: 869). The impact of these policies on Burma will be examined in more detail in the next section. In the early 1930 almost $45 \%$ of Burmese imports came from India and a further $22 \%$ from Britain (Table 8 ). The very high reliance on imports from India did not change much after the formal separation of Burma from India in $1937 .^{9}$

Although Thailand was not a colony, the influence of British financial advisers in the Kingdom was considerable up to 1932, and it was certainly the case that as late as 1929-33, the proportion of total imports from Britain was rather higher than the British share of world exports (Table 8). The Bowring Treaty, and similar treaties signed with other powers in the latter part of the nineteenth century had deprived Thailand of any capacity to use tariffs for protective purposes, but by 1926 these treaties had been revoked and tariff

\footnotetext{
${ }^{9}$ Andrus (1948: 187-92) discusses Burma-Indian trade after formal separation. He takes issue with those writers who argued that Burma benefited from having the large Indian market for Burmese rice exports, and suggests that Burma would have been able to dispose of its rice surplus on the world market without greatly depressing world prices.
} 
autonomy substantially achieved (Ingram 1971: 147). But only very limited use was made of tariffs as a means of fostering domestic industry. As we will see below, Thailand's liberal trade regime, combined with the fact that the agricultural economy remained reasonably buoyant through the 1930 s, led to a considerable growth in imports from various sources, especially Japan. Indeed Japan had become such an important exporter to most parts of the region by the mid-1930s that it is often difficult to disentangle trade policies designed to respond to the world depression from those designed to counter the perceived Japanese 'threat'. I now look at both types of policies in more detail.

Trade Policies in the I93os: Responding to Growing World Protectionism and the Japanese 'Threat'. One of the most striking aspects of the development of intra-Asian trade in the inter-war years was the growth of Japanese exports. After 1920, Japan, as a "newly industrialising nation' embarked on the kind of export strategy which the erstwhile Japanese colonies, South Korea and Taiwan, were to adopt in the 1960s, and many other Asian countries after 1980. Labour-intensive industries such as textiles and garments, footwear and household utensils which had been producing largely for the domestic market began to penetrate export markets in other parts of Asia. Because industrial labour was much cheaper in Japan than in the more mature industrial economies of West Europe and North America, Japanese products could be priced very competitively and they found a ready market among millions of consumers who were more concerned about price than quality. In 1920, over half of total Japanese exports were going to Asia, and this percentage did not change greatly until the latter part of the 1930s. A high proportion of the Asian share of Japanese exports went to those parts of Asia which were under the control of the British, Dutch and Americans (Table 9).

That it suited the interests of powerful lobbies in British Malaya, the Netherlands Indies and the Philippines to have cheap Japanese wage goods flooding into these colonies in the early 193 os cannot be doubted. ${ }^{10}$ Large estate companies were desperate to hold down labour costs as prices for primary products slumped after 1930, and world markets contracted. In the case of the Netherlands Indies, the competitive position of key export industries such as rubber and sugar was further damaged by the Dutch decision to stay on the gold

${ }^{10}$ See Brown (1994) for a discussion of the response in British Malaya. 
TABLE 9

Japanese Exports to Selected Asian Countries, I9I3-I942 (million yen)

\begin{tabular}{|c|c|c|c|c|c|c|}
\hline Year & Asia $^{a}$ & $\begin{array}{l}\text { British } \\
\text { India }\end{array}$ & Thailand & $\begin{array}{l}\text { Netherlands } \\
\text { India }\end{array}$ & Philippines & $\begin{array}{c}\text { French } \\
\text { Indochina }\end{array}$ \\
\hline 1913 & 275.9 & 29.9 & 1.0 & 5.1 & 6.3 & 1.1 \\
\hline 1920 & 998.4 & 192.2 & 4.2 & 107.2 & $34 \cdot 4$ & $3 \cdot 4$ \\
\hline 1925 & 1000.6 & $173 \cdot 4$ & 7.8 & 85.6 & 29.3 & 4.0 \\
\hline $193^{\circ}$ & 704.0 & $129 \cdot 3$ & $9 \cdot 5$ & 66.0 & 28.4 & 2.4 \\
\hline 1931 & $5^{\circ} 5 \cdot 5$ & 110.4 & $4 \cdot 7$ & 63.5 & 20.4 & 1.7 \\
\hline 1932 & 677.6 & 192.5 & 8.6 & 100.3 & 22.4 & 2.3 \\
\hline 1933 & 930.6 & 205.2 & 18.1 & 157.5 & 24.1 & $3 \cdot 7$ \\
\hline 1934 & 1169.5 & $23^{8.2}$ & 28.0 & $15^{8.5}$ & $3^{6.5}$ & 2.7 \\
\hline 1935 & $1304 \cdot 4$ & 275.6 & 40.3 & 143.0 & 48.1 & 4.0 \\
\hline $193^{6}$ & 1370.9 & 259.1 & 43.0 & 129.5 & $5^{1.8}$ & $4 \cdot 7$ \\
\hline 1937 & 1645.9 & $299 \cdot 4$ & $49 \cdot 4$ & 200.1 & 60.3 & 4.6 \\
\hline $193^{8}$ & 1664.7 & 188.0 & $39 \cdot 3$ & 188.0 & 32.6 & 3.1 \\
\hline 1939 & 2320.3 & 211.0 & 26.0 & 137.8 & $24 \cdot 7$ & 2.0 \\
\hline $194^{\circ}$ & 2493.9 & 233.5 & $49 \cdot 3$ & $173 \cdot 4$ & 26.7 & 2.6 \\
\hline $194^{1}$ & 2155.1 & 163.2 & $6_{5} .6$ & 161.0 & $13 \cdot 4$ & $45 \cdot 4$ \\
\hline 1942 & 1748.7 & $\mathrm{O}$ & 66.5 & 15.7 & 1.3 & 144.4 \\
\hline
\end{tabular}

${ }^{a}$ Excluding Japanese colonies but including China and Hong Kong.

Source: Japan Statistical Yearbook 1949, pp. 476-7.

standard after 1931. Because the Netherlands Indies was a more open and less protected economy than the Philippines as well as being a much larger market, it is not surprising that Japanese exports into that market were much larger in absolute terms than those to the Philippines. But they also comprised a greater share of total imports, especially after 1930 (Table 10). Given the increasing power of the militarist factions in the Japanese government, it was inevitable that the Dutch colonial authorities began to worry about the political and strategic motives behind the rapid growth of Japanese exports. Certainly Japanese government agencies were deeply involved in the export expansion into South East Asia, and the huge Indonesian archipelago was, in the eyes of the Dutch colonial establishment, especially vulnerable to Japanese 'subversion by trade' (van Gelderen 1939: $21 \mathrm{ff}$ ).

The first years of the world slump were especially damaging to the Netherlands Indies not just because of falling prices for key export staples but also because of contracting markets. As both the British and French empires retreated into greater protectionism, it became increasingly difficult to sell products such as sugar into either British or French territory. Given that the metropolitan market in the Netherlands for tropical products was small, and the Dutch pos- 
TABLE 10

Percentage of Total Imports from Japan

\begin{tabular}{|c|c|c|c|c|c|}
\hline Year & Thailand & Philippines & FIC & NEI & Burma \\
\hline 1923 & n.a. & 9.2 & 0.6 & 7.6 & $5 \cdot 0$ \\
\hline 1924 & n.a. & $7 \cdot 9$ & 1.4 & $9 \cdot 5$ & 6.7 \\
\hline 1925 & n.a. & 9.1 & 2.7 & 10.4 & $7 \cdot 9$ \\
\hline 1926 & n.a. & $9 \cdot 7$ & 2.9 & 8.9 & 6.7 \\
\hline 1927 & n.a. & 9.6 & 2.4 & $9 \cdot 7$ & 6.4 \\
\hline 1928 & 2.8 & 9.6 & 2.1 & 9.1 & 6.5 \\
\hline 1929 & 8.1 & 8.1 & 1.8 & 10.4 & 8.4 \\
\hline $193^{\circ}$ & 11.2 & 10.5 & 1.1 & 10.9 & 8.9 \\
\hline $193^{1}$ & 8.4 & 11.1 & 1.6 & 15.2 & 8.9 \\
\hline 1932 & $14 \cdot 4$ & 7.8 & 1.1 & 19.1 & 11.6 \\
\hline 1933 & 19.2 & 8.4 & 2.2 & 29.8 & $9 \cdot 4$ \\
\hline 1934 & $25 \cdot 3$ & 12.4 & 2.2 & $3^{1.9}$ & $9 \cdot 3$ \\
\hline 1935 & 29.1 & 14.2 & $3 \cdot 3$ & $29 \cdot 5$ & 10.9 \\
\hline $193^{6}$ & 28.3 & 13.1 & 3.1 & 26.2 & 10.6 \\
\hline 1937 & 21.5 & 14.8 & 3.2 & 24.2 & 8.3 \\
\hline $193^{8}$ & 15.6 & 9.6 & 3.1 & 14.5 & 6.6 \\
\hline 1939 & 9.6 & 6.2 & 1.7 & 16.1 & $7 \cdot 1$ \\
\hline
\end{tabular}

Source: Thailand: Swan (1988: 76); FIC: Service de la statistique générale (1947); Philippines: Bureau of Census and Statistics (1941); Netherlands Indies: Korthals Altes (1991); Burma: National Planning Commission (1960), Statistical Appendix.

sessed few other colonial territories, there was little option but to cut back production. In 1929/30, when Java sugar production was at its peak, it was more than three times that of the Philippines. By $1935 / 6$, Javanese production had fallen to only about $20 \%$ of the 1929/30 level while that in the Philippines had surpassed Javanese production by almost $50 \%$ (Booth 2000: Table 14.4). ${ }^{11}$

Given these problems in leading export industries, it was hardly surprising that Dutch free-trade principles were tested beyond their limits, and 'the idea rapidly spread that the unlimited free trade and open-door policy, which governed the whole foreign trade of the Netherlands, including its inter-imperial relations, had to be reconsidered in the light of post-crisis conditions' (van Gelderen 1939: 30). The new policies took two main forms. On the one hand trading links between the metropolitan economy and the Indies were strengthened by policies designed to reserve a large share of the

\footnotetext{
${ }^{11}$ Most contemporary reports stressed the technical backwardness of the Philippine sugar industry compared with the Javanese one. Corpuz (1997: 252) suggests that one reason for this was that Philippine sugar cultivation was in the hands of a large number of small and medium-scale producers, all of whom were Philippinos. Unlike the situation in Java, growers devoted no resources to development of better cultivation technologies.
} 
Dutch metropolitan market for colonial imports of sugar, corn and vegetable oils. In the case of sugar the Netherlands guaranteed a quota of 85 , ooo tons annually, in spite of protests from Dutch sugar beet producers. Van Gelderen pointed out that these quota allocations were granted in part as a compensation for the implementation of the second class of policies which involved imposing quotas on imports into the Netherlands Indies for a range of imports. Some goods were subject to general quotas, which enabled colonial importers to purchase from the cheapest source (usually Japan) but other goods were subject to specific country quotas. Typically cheap cotton goods, and some household utensils were subject to general quotas, while superior textile products, paper products, rubber tyres, chemical manures, light bulbs etc were subject to country quotas.

The purpose of this system was to reserve a share of the colonial market for Dutch, and to a lesser extent other European, producers. It led to a marked downturn in the percentage share of Japanese imports in total imports of the Indies from the peak reached in 1935, although in absolute terms Japanese exports reached a peak in 1937, and fell thereafter (Tables 7 and 8). In the Philippines, commercial interests in the USA were also putting the colonial administration under strong pressure to place tariffs or quantitative restrictions on Japanese imports, especially of cotton textiles. Mindful of the approach of self-government, and also concerned about the impact of trade restrictions on prices of important consumer goods, the Bureau of Insular Affairs, the main agency responsible for economic policy, took a cautious approach to the imposition of import controls in 1934-5. But US congressional pressure grew, and key senators such as Millard Tydings began to suggest that if restrictions on Japanese imports were not imposed, the USA would take a much tougher approach to the granting of duty free access into the US market for Philippine agricultural exports. Negotiations dragged on through 1935 between the American and Japanese governments; the upshot was that Japanese yarn and textile producers agreed to a system of voluntary export restrictions to the Philippine market (Guerrero 1994: 175-9).

Japanese exports to the Philippines were never especially large in relation to total Japanese exports, and the Japanese government no doubt reasoned that it was more prudent to appease the American congress than to increase commercial penetration of the Philippine market. After self-government was granted the absolute value of Japanese exports fell, as did the share of Japan in total Philippine 
exports (Tables 7 and 8). In French Indochina by contrast, Japan was never able to get more than a tiny share of the total import market, and the absolute value of Japanese exports into Indochina was minuscule. Indeed, the balance of trade between Japan and Indochina ran in favour of Indochina throughout the 193 os $^{12}$ (Rahm 1952: Table XVII). What explains this failure? As I will argue below, exchange rate policy is unlikely to have accounted for the persistent trade surpluses as the piastre appreciated against the yen in real terms for much of the decade. We must seek the explanation in terms of trade policy.

Norlund (2000: 216) presents a useful analysis of the tangle of vested interests, both in the colony and in metropolitan France, which affected trade policy decisions in French Indochina as the world crisis deepened:

agricultural interests in France wanted the French market to be protected from colonial imports; French industrialists wanted protection for their goods in the colonial market; colonial agricultural interests wanted the abolition of restrictions on the import of their production into France and opposed the protection of French goods in the colonial market. The Comite de l'Indochine lobbied effectively for protection for Indochinese crops. Its greatest achievement was to secure a free loan of 100 million francs in 1932 for French rubber plantations ...

Faced with this barrage of contradictory demands, the French colonial administration decided to restrict imports from other parts of Asia, and especially from Japan and China. As far as the Japanese were concerned, there is some evidence that they viewed the Indochina market in a rather different light from markets in other parts of colonial Asia, such as British India or the Netherlands Indies. No doubt French tariff policies accounted for much of the Japanese hesitation. Touzet (1934: 151) quotes a former Japanese Consulgeneral in Hanoi as stating in 1930 that 'Japan has much to ask of Indochina but nothing to offer her'. This was certainly not the Japanese view regarding Dutch and British colonies. It appears that the robust nature of the French response to any sign of interest in the Indochina market on the part of Japanese exporters after 1930 served as a potent deterrent, or at least persuaded Japanese textile exporters, to take one example, to target other parts of Asia where colonial governments were more laissez faire in their trade regimes. After the tariff changes of 1928-9, French textile interests lobbied

12 The main exports from Indochina into Japan were rice and coal. 
hard to prevent any imports into Indochina from Japan, and in 1932 (at least two years before either the Dutch or the Americans were stirred into action), the Japanese and French governments signed a trade accord which regulated trade between Japan and Indochina. A list of products which the Japanese could export to Indochina with an agreed reduction in the general tariff was drawn up; in Touzet's words the list was 'sans doute un peu limité' but it was made clear to the Japanese that that was all they were going to get.

Even a senior colonial official like Touzet was somewhat ambivalent about the impact of this aggressive protectionism; he acknowledged that the level of trade between Indochina and Japan was 'derisory' and expressed the view that it could, and should expand. But on the other hand he also pointed out that Japan engaged in trade practices which were potentially dangerous to Indochina; these included not only 'currency dumping' through the depreciation of the yen, but also dumping of manufactures at prices made possible by 'salaries dérisoires, longues heures de travail' (Touzet 1934: 156). Touzet notes the export offensive which the Japanese mounted against both British India and the Netherlands Indies and pointed out that Indochina had been spared most probably because of the relatively small size of her market. But the nature of French protectionism was almost certainly the most important explanation, and Japanese exports to Indochina were to expand rapidly after 1941, when the disruption of trade links with France made it a far more open and attractive market for Japanese manufactures. ${ }^{13}$

The robust nature of the French protectionist response in Indochina can be contrasted with the situation in Burma, where a form of 'double colonialism' prevailed. Given that Burma in the early 1930 s was simply a province of British India with no autonomy in economic policy, trade policy was determined in New Delhi and London. Japanese exports to British India as a whole almost trebled in terms of nominal yen between 1931 and 1937, in spite of the imposition of imperial preference in 1932 and high tariffs on

\footnotetext{
${ }^{13}$ It seems that in Indochina large agricultural estates did not have the same political influence that they had in the Netherlands Indies or in British Malaya, and thus the pressures to allow in cheap wage goods were not as intense. Schweitzer (1971: 238-9) suggests that the main aim of lobby groups acting on behalf of Indochinese estates was to increase the tariff on foreign tea imports into France, and to organize interest-free loans for the rubber plantations in Indochina, which, as Norlund points out, was probably the main achievement of agricultural producer lobbies within the colony.
} 
Japanese textile imports in 1933. Japanese imports into Burma reached $11.6 \%$ of total imports in 1932 , and although the percentage declined slightly over the next two years, Japanese imports still comprised almost $11 \%$ of total exports in $1935 / 36$, suggesting that the effect of the protectionist measures adopted in 1932-33 was at best transitory. There was of course no large-scale domestic textile industry in Burma to protect from foreign competition, either from the rest of India, Britain or Japan. The desire to keep the price of wage goods cheap must have been an important factor weighing on the minds of British administrators in Burma, and as Brown (2000) argues, there is little evidence that textile imports declined on a per capita basis after 1931 .

In Thailand, where the government was not under the same pressure from metropolitan vested interests in determining tariff policies, the share of Japan in total imports increased sharply after 1931, and by 1935 was as high as the Netherlands Indies (Table 8). The Thai government which had come to power after the 1932 coup against the absolute monarchy did not share the fears of the Dutch or the British about Japanese intentions in South East Asia. The decline in imports from Japan as a percentage of total Thai imports after $1936 / 7$ was mainly due to Chinese merchants boycotting Japanese goods and replacing them with goods from other countries (Swan 1988: 95-6). But the boycott eventually crumbled and after the European war made it increasingly difficult to obtain imports from the UK and elsewhere, the Japanese share increased again.

Exchange Rate Policies. We have seen that, in relation to one another, and to other important currencies such as the yen and (except the Philippines) the dollar, nominal exchange rates in the colonies followed the movements of the metropolitan currencies over the 1930s. Relative to the dollar, the piastre first appreciated, along with the franc, and then depreciated after 1936 (Bassino 1998, Figure 1). This was also the path followed by the sterlingbased currencies, the baht and the rupee (Van der Eng 1993: 28). The Indonesian guilder underwent a sharp appreciation against the dollar until 1936 when the Netherlands finally decided to go off the gold standard. The yen by contrast left the gold standard in December 1931, after the Japanese had lost 675 million yen in gold in a vain attempt to defeat speculators, and thereafter depreciated rapidly against both the dollar and sterling, and the other currencies pegged to them (Kindleberger 1987: 163-4). By 1935, the yen had lost more than half its value against 
the various South East Asian currencies; the nominal devaluation was especially steep against the Indies guilder.

In the Netherlands Indies, there was a sharp deflation during the years from 1929 to 1936 ; by 1936 the cost of living for low income indigenous families in Batavia (Jakarta) was only half what it had been in 1929 (Booth 2000, Table 4.5). But given the magnitude of the nominal appreciation, the deflation was insufficient to restore the real value of the guilder against the yen (Booth 1994: Table 6.8). In Indochina where the rate of deflation was far more modest, the piastre appreciated sharply against the yen between 1931 and 1935; indeed, the real exchange rate of the piastre against the yen only returned to its 1931 value in 1937 (Booth 2000, Table 4.6). Given the extent of the appreciation against the yen, why did Japanese imports not flood into Indochina? The answer lay in the ever more stringent controls applied by the French against all imports originating from outside the French Empire. As I have already argued, the French administration faced a complicated set of demands from diverse vested interests in both the colony and metropolitan France as the crisis deepened. But ultimately, considerations of imperial preference obviously weighed more heavily in the minds of the French than those of consumer welfare in the colony.

The departure from gold certainly made Thai rice exports more competitive, as Sompop (2000: 192) argues, although the price advantage was offset in several key markets by the import controls which many rice-importing countries in Asia and elsewhere imposed after 1932. In addition Thai rice exports were of higher quality than those from Vietnam and Burma, and consumers in important markets such as neighbouring Malaya switched to less expensive rice as their incomes fell. But in spite of these problems Thai rice exports recovered in volume terms quite rapidly from the low point reached in 1930, and the average annual tonnage exported in $193^{6}-38$ was some 13 per cent higher than the average for 1928-30. The Thai government was sensitive to the problems of rural producers, and realized that exchange rate policy alone was insufficient to boost rural incomes. After 1932, both the tax on rice fields and the poll tax were reduced, and many agricultural debts were written off (Sompop 2000: 194-5). 


\section{Would Alternative Policies Have Made a Difference?}

This comparative study of the responses of four colonial regimes, and one nominally independent one, in South East Asia to the world crisis of the 1930 s has tried to clarify and explain the differences in these responses. In the case of the colonies, administrators in British Burma, the Philippines, the Netherlands Indies and French Indochina had to deal with a range of often contradictory demands from powerful vested interests both in the colony and in the metropolitan power. In addition all were concerned, to a greater or lesser extent, with the economic and strategic threat posed by Japan. It is true that colonial administrators everywhere in South East Asia were also concerned about the welfare of the indigenous population, and wanted to protect them, to the greatest extent possible, from the effects of the worldwide economic blizzard raging around them. But they were often constrained in what they could do by powerful economic interests both in the colony and at home.

But even if they had not faced these constraints, would alternative policies have made a difference, both to economic growth and to popular welfare? In this section, I try to answer this question for each of the five economies in turn.

French Indochina. There can be little doubt that the French authorities in Indochina adopted the most robustly protectionist policies, especially with respect to Japan. Defenders of the trade and exchange rate policies adopted over the 1930 argued that total export volume from Indochina rose quite rapidy after 1930, and certainly more rapidly than in the Netherlands Indies, the other colony which stayed with its metropolitan counterpart on the gold exchange standard until 1936 (Table 1). Touzet (1939: 244ff) pointed out that rice exports after falling from 1.47 million tonnes in 1929 to only 960,000 tonnes in 1931 , rose steeply to almost 1.8 million tonnes by $1936 .{ }^{14}$ The increase in exports was almost entirely due to expanded exports to metropolitan France and the French colonies; of the non-French markets for Indochinese rice which had been important prior to 1930 , only British India was importing an increased quantity by 1937 . Touzet made much of the fact that Indochina could still manage to export rice to India in spite of the depreciation of the rupee relative to the piastre. He argued, no doubt

\footnotetext{
${ }^{14}$ Exports of manufactured goods also increased between 1935 and 1938, especially cement and cotton fabrics. See Mitchell (1942), Table 44 .
} 
correctly, that it was not exchange rate policy per se but rather the change in French agricultural protectionism which permitted the rapid expansion of rice exports from Indochina into France and the French Empire, and pointed out that (as with the case of Philippine sugar exports to the USA), having a protected metropolitan market to sell into proved a great boon to colonial agricultural exporters during a period of contracting world markets.

On the other hand, the policy of protectionism did lead to higher costs in French Indochina compared to neighbouring countries. Norlund (2000: 218) quotes the estimate of Pierre Bernard that prices in Indochina were $15 \%$ above those in other parts of Asia. The complaints of the rubber estates that the high cost of wage goods was reducing their competitiveness in world markets were met with substantial interest-free loans, and rubber exports grew by more than six-fold between 1930 and 1939 (Takada 2000: Table 9). But other sectors with less political influence were not assisted. The evidence that real wages did not decline between 1930 and 1936 could be used as evidence that the franc-piastre peg did not harm the welfare of wage and salary workers (Giacometti 2000: 192). But the vast majority of the population in Vietnam were not working for wages in the urban economies of Hanoi and Saigon. They suffered from higher prices than would have prevailed with a more open trade regime, and from reduced employment opportunities.

The key issue concerns the exchange rate. What if the piastre had been left to float in 1930? A floating rate combined with controls over the capital account of the balance of payments would obviously have given the colonial government greater power to pursue anticyclical fiscal and monetary policies. Arguably such policies could have led to more rapid economic diversification, especially in the north where the population pressure on land was already intense. Given that budgetary expenditures were smaller in per capita terms in Vietnam compared with other parts of South East Asia, an increase in expenditures on both capital works and health and education would have contributed to increased productivity and improved living standards over the decade.

Norlund (1991: 88-9) has argued that French tariff policies did not completely prevent industrialization for the domestic market in Indochina, any more than American tariff policies did in the Philippines. Indeed, by the 1920s, Indochina had achieved a considerable level of industrialization, and there was a thriving handicraft sector (Shepherd 1941: 9ff; Mitchell 1942: 153ff). A different trade and 
exchange rate regime in the 193 os could have built on this foundation, leading to a more diversified export sector with manufactured goods accounting for a higher proportion of total exports. In the event such export diversification had to wait until the mid-1980s, when the communist regime adopted a floating exchange rate, and a trade regime more conducive to export growth.

Philippines. To an even greater extent than was the case in French Indochina, the agricultural economy of the Philippines benefited from access to the protected American market. But the benefits clearly accrued disproportionately to the sugar producers, the largest of whom exercised considerable influence over economic policymaking, both before and after 1935. Their influence was exclusively brought to bear on the issue of the sugar quota in the USA; the broader issue of the peso-dollar parity rate seems to have been of less concern (Corpuz 1997: 254-5). But as Hooley (1996: 296) argues, there is evidence that the rate of two pesos to the dollar represented an overvaluation of the peso even in 1904; after 1920 when the terms of trade of the Philippines began to decline, the consequences of the over-valuation were increasingly serious for all traded goods producers. The sugar producers, by negotiating quotas in the American market, in effect secured a subsidy for their exports, whereas an across the board devaluation would have assisted all producers of exports and import substitutes. Hooley (1996: 297) wryly points out that the irony of this policy was that the American government, then as now ideologically committed to a free market philosophy, 'would end up erecting a trade regime in the Philippines which was a monument to interventionism'. This legacy carried over into the post-1945 era, and indeed survived until the 1980 s.

Netherlands Indies. If important export sectors such as rice in French Indochina and sugar in the Philippines benefited from protected markets either in the metropolitan economy or in other parts of the imperial trading system, key export industries in the Netherlands Indies benefited to only a very limited extent from this form of protection. The most obvious example was the sugar industry whose contraction after 1930 was entirely due to loss of markets especially in the British Empire. Colonial officials might have been expected to respond to this disaster with a devaluation of the Indies guilder which would at least have allowed sugar producers to compete more aggressively in the markets which were still open to them. But the Netherlands government was determined to keep both currencies on the gold standard, so that domestic deflation, and direct controls, 
were the only policy tools left to assist the traded goods sectors. As we have seen, the deflation, although severe, was not enough to bring about a real depreciation of the guilder against other regional and world currencies. The appreciation was especially sharp against the yen.

The inevitable result was that the colonial authorities resorted increasingly to extensive regulation of both exports and imports after 1934; to quote van Gelderen (1939: 41), 'government regulation ... proved to be the only way out'. In 1934, Japan supplied over $30 \%$ of total imports into the Indies by value (compared with only $13 \%$ from the Netherlands). The ratio fell after restrictions were applied. The latter part of the 1930 s saw the imposition of an extensive regime of import licensing (Booth 1998: 218-22). The net effect of this regime was not so much to slow down growth in imports (which was in fact quite rapid as the economy began to recover after 1935), but rather to protect imports from the Netherlands and other favoured countries against competition from Japan. Even so, the Indies market remained by far the largest in South East Asia for Japanese exporters right up until 1941 (Table 9). But the much vaunted commitment to free trade principles had been severely eroded, and it was a regulated rather than a laissez faire trade regime which was bequeathed to the post-independence government.

Burma. A comparison of the available national income estimates shows that Burma suffered most severely from the impact of the world crisis. Per capita net domestic product was still almost 20\% below the 1931 figure by 1938 (Table 4 ). This was rather surprising, in that although the volume of rice exported fell after 1934-35, the extent of the decline (about 7.2\%) was no where near severe enough to explain the sharp contraction in agricultural output which Aye Hlaing found between 1931/2 and 1938/9 (Table 5). Indeed, the ratio of exports to net domestic product increased after 1931 (Table 2). As in Indochina, the impact of the nominal appreciation of the rupee against the yen on imports from Japan was dampened by the imposition of tariffs on Japanese imports. The absence of domestic price indices in either Burma or Thailand make it difficult to assess the extent of the real appreciation of the rupee and the baht against the yen, but it was probaby not very different from that which occurred in Indochina. So without protection it is likely that Burmese consumers would have benefited from cheaper wage goods, especially textiles. There was indeed justice in the Burmese complaint that 
the Burmese consumer was being taxed to protect a textile industry located in other parts of India.

Two tentative explanations can be advanced to explain the severe fall in national income per capita over the decade. By the 1930 s Burma was no longer a land-abundant economy in the sense that Thailand still was, or indeed the outer islands of Indonesia, or southern Vietnam and Laos. Thus the scope for agricultural expansion and diversification was limited. And as Brown (1999) has argued, the problem was compounded by the extent and the severity of rural indebtedness. A second explanation, and in my view the more important, concerns the status of Burma as a province of British India. One adverse consequence of this was the large imbalance between revenue collections (which were a much higher proportion of domestic product in Burma than in British India or in any other part of South East Asia) and government expenditures in Burma. In addition, Burma's status as a province of India was detrimental to the industrialization in the 1930s. Unike Vietnam, the Philippines or the Netherlands Indies, the colonial government made no attempt to foster industrial diversification in the wake of the world crisis. There was some opportunity to do so after the formal separation from India, but there is little evidence that the opportunity was taken. Burma remained an overwhelmingly agricultural economy; not just were manufactures imported from India and elsewhere but most services were in effect supplied from other parts of British India. That this had a damaging effect on the post-colonial development of independent Burma seems undeniable.

Thailand. Alone among the five economies being considered here, Thailand was not a colony and the Thai government did have some autonomy in policy formulation. There is little evidence that this autonomy made much difference to macroeconomic policy over the decade. Until 1935, fiscal policy was indeed more conservative than in the Netherlands Indies, or Indochina, and a rigid peg to sterling was maintained from 1932 until 1941 (Ingram 1971: 337). Thailand lacked any protected imperial market into which its rice or other exports could be sold, and this certainly affected its rice sales, although total export volume held up quite well over the 1930s. The Thai government did take steps to reduce rural tax burdens, and also increased expenditures on capital works in the latter part of the decade. But on balance Thailand, as Ingram argued, probably 'weathered the storm' better than its South East Asian neighbours 
not because of any overt government interventions, but because of its relative land abundance, and the subsistence orientation of most agricultural producers. There were few large agricultual enterprises run along capitalist lines which suffered from the collapse of both prices and markets, as did Javanese sugar producers, for example. Neither did large numbers of Thais depend on wage labour for most of their income as was the case in Java and Northern Vietnam, or indeed in Peninsular Malaya and Singapore. Most Thai rice farmers did not have large debts which they could no longer service from falling incomes, as was the case in Burma. And the Thai government, less concerned about Japanese import penetration, was prepared to allow cheap imports to flow in. The 193 os were thus a less traumatic decade for Thailand than for other parts of the region, and the impact of the world crisis on subsequent policymaking was less obvious.

\section{Bibliography}

Andrus, J. R. 1948. Burmese Economic Life. Stanford: Stanford University Press.

Ark, Bart van. 1986. 'Indonesian Export Growth and Economic Development: 117 Years of Empirical Evidence, 1823 to 1940', Research Memorandum nr I 89. Institute of Economic Research, Faculty of Economics, University of Gröningen.

Aye Hlaing. 1964. 'Trends of Economic Growth and Income Distribution in Burma, 1870-1940', Journal of the Burma Research Society, Vol. XLVII, June, pp. 89-148.

Aye Hlaing. ${ }^{1965}$. An Economic and Statistical Analysis of Economic Development of Burma under British Rule. PhD Dissertation, University of London.

Banens, Maks. 200o. 'Vietnam: A Reconstruction of its 2oth Century Population History' in Jean-Pascal Bassino, Jean-Dominique Giacometti and K. Odaka (eds). Quantitative Economic History of Vietnam I900-1990. Tokyo: Hitotsubashi University, Institute of Economic Research.

Bassino, Jean-Pascal. 1998. 'Exchange Rates and Exchange Rate Policies in Vietnam under French Rule (1895-1954)', Discussion paper D98-8, Tokyo: Hitotsubashi University, Institute of Economic Research.

Bassino, Jean-Pascal. 2000. 'Public Finance in Vietnam under French Rule, 18951954 ' in Jean-Pascal Bassino, Jean-Dominique Giacometti and K. Odaka (eds). Quantitative Economic History of Vietnam I900-1990. Tokyo: Hitotsubashi University, Institute of Economic Research.

Bassino, Jean-Pascal. 2001. 'Preliminary Estimates of Vietnam GDP (1800-1970): North-South Economic Divide in Historical Perspective', Paper presented to the International Workshop on Asian Historical Statistics Database, Tokyo: Hitotsubashi University, Institute of Economic Research, January.

Bassino, Jean-Pascal and Bui Thi Lan Huong. 200o. 'Estimates of Indochina's and Vietnam's International Trade (1890-1946) in Jean-Pascal Bassino, Jean-Dominique Giacometti and K. Odaka (eds). Quantitative Economic History of Vietnam 1900-1990. Tokyo: Hitotsubashi University, Institute of Economic Research. 
Bassino, Jean-Pascal and Hironobu Nakagawa. 2000. 'Exchange Rates and Exchange Rate Policies in Vietnam under French Rule, 1878-1945' in Jean-Pascal Bassino, Jean-Dominique Giacometti and K. Odaka (eds). Quantitative Economic History of Vietnam I90o-1990. Tokyo: Hitotsubashi University, Institute of Economic Research.

Batson, Benjamin A. 1984. The End of the Absolute Monarchy in Siam. Singapore: Oxford University Press.

Birnberg, Thomas B. and Stephen A. Resnick. 1975. Colonial Development: An Econometric Study. New Haven: Yale University Press.

Booth, Anne. 1994. 'Japanese Import Penetration and Dutch Response: Some Aspects of Economic Policy Making in Colonial Indonesia' in Shinya Sugiyama and M. G. Guerrero (eds). International Commercial Rivalry in Southeast Asia in the Interwar Period. Monograph 39, Yale Southeast Asia Studies, New Haven: Yale Center for International and Area Studies.

Booth, Anne. 1998. The Indonesian Economy in the Nineteenth and Twentieth Centuries: A History of Missed Opportunities. London: Macmillan.

Booth, Anne. 2000. 'Crisis and Response: A Study of Foreign Trade and Exchange Rate Policies in Three Southeast Asian Colonies in the 1930s' in Peter Boomgaard and Ian Brown (eds). Weathering the Storm: The Economies of Southeast Asia in the I93os Depression. Leiden: KITLV Press and Singapore: Institute of Southeast Asian Studies.

Brown, Ian. 1986. 'Rural Distress in Southeast Asia During the World Depression of the Early 1930s: A Preliminary Reexamination', Journal of Asian Studies, Vol. XLV (5), November, pp. $995^{-1025}$.

Brown, Ian. 1994. 'The British Merchant Community in Singapore and Japanese Commercial Expansion in the 1930s' in Shinya Sugiyama and M. G. Guerrero (eds). International Commercial Rivalry in Southeast Asia in the Interwar Period, Monograph 39, Yale Southeast Asia Studies, New Haven: Yale Center for International and Area Studies.

Brown, Ian. 1999. 'The Economic Crisis and Rebellion in Rural Burma in the Early 1930s' in R. Minami, K. S. Kim and M. Falkus (eds). Growth, Distribution and Political Change: Asia and the Wider World. London: Macmillan.

Brown, Ian. 2000. 'Material Conditions in Rural Lower Burma During the Economic Crisis of the Early 1930s: What the Cotton Textile Import Figures Reveal' in Peter Boomgard and Ian Brown (eds). Weathering the Storm: The Economies of Southeast Asia in the I93os Depression. Leiden: KITLV Press and Singapore: Institute of Southeast Asian Studies.

Bureau of Census and Statistics. 1941. Yearbook of Philippine Statistics 1940. Manila: Bureau of Census and Statistics, Commonwealth of the Philippines.

Central Bureau of Statistics. 1947. Statistical Pocketbook of Indonesia I94I. Batavia: G. Kolff.

Chatthip Nartsupha, Suthy Prasartset and Montri Chenvidyakarn. 1981. The Political Economy of Siam I9IO-1932. Bangkok: Social Science Association of Thailand.

Chaudhuri, K. N. 1983. 'Foreign Trade and the Balance of Payments, (1757-1947)' in Dharma Kumar (ed.). The Cambridge Economic History of India, Vol. 2: cI757c I970. Cambridge University Press.

Clark, Grover. 1936. The Balance Sheets of Imperialism: Facts and Figures on Colonies. New York: Columbia University Press.

Corpuz, O. D. 1997. An Economic History of the Philippines. Manila: University of the Philippines Press.

Greutzberg, P. 1976. Changing Economy in Indonesia, Volume 2, Public Finances I 816 1939. The Hague: Martinus Nijhoff. 
Department of Economic Affairs (1938). 'Prices, Price Indexes and Exchange Rates in Java, 1913-1937', Bulletin of the Central Bureau of Statistics 46. Batavia: Central Bureau of Statistics.

Espino, Jose. 1933. The American Tariff Policy in the Philippines. Manila: Institute of Pacific Relations.

Fowler, John A. 1923. Netherlands East Indies and British Malaya: A Commercial and Industrial Handbook. Washington: Government Printing Office for the Department of Commerce.

Friend, Theodore. 1963. 'The Philippine Sugar Industry and the Politics of Independence, 1929-1935', Journal of Asian Studies, Vol. 22, pp. 179-92.

Friend, Theodore. 1965. Between Two Empires: The Ordeal of the Philippines I929-1946. New Haven: Yale University Press.

Gelderen, J. van. 1939. The Recent Development of Economic Foreign Policy in the Netherlands East Indies. London: Longmans, Green.

Giacometti, Jean-Dominique. 2000. 'Wages and Consumer Price for Urban and Industrial Workers in Vietnam under French Rule (1895-1954)' in Jean-Pascal Bassino, Jean-Dominique Giacometti and K. Odaka (eds). Quantitative Economic History of Vietnam I900-I990. Tokyo: Hitotsubashi University, Institute of Economic Research.

Gonggrijp, G. 1931. 'Repartition des activités economiques entre les Colonies et la Metropole', Proceedings of the Institut Colonial International, XXI Session, Paris, May 1931.

Guerrero, Milagros. 1994. 'Japanese-American Trade Rivalry in the Philippines, 1919-41' in Shinya Sugiyama and M. C. Guerrero (eds). International Commercial Rivalry in Southeast Asia in the Interwar Period. Monograph 39, Yale Southeast Asia Studies, New Haven: Yale Genter for International and Area Studies.

Hooley, Richard W. 1968. 'Long-term Growth of the Philippine Economy, 19021961', Philippine Economic Journal, Vol. VII (1), pp. 1-24.

Hooley, Richard. 1996. 'A Century of Philippine Foreign Trade: A Quantitative Analysis' in E. Di Dios and R. Fabella (eds). Choice, Growth and Development: Essays in Honour of Jose Encarnacion. Manila: University of the Philippines Press.

Huff, W. G. 2001. 'Entitlements, Destitution and Emigration in the 1930s Singapore Great Depression', Economic History Review, Vol. LIV (2), May, pp. 290323 .

Ingram, J. 1971. Economic Change in Thailand, I850-1970. Kuala Lumpur: Oxford University Press.

Jenkins, Shirley. 1954. American Economic Policy towards the Philippines. Stanford: Stanford University Press.

Kindleberger, Charles P. 1987. The World in Depression, 1929-1939. Harmondsworth: Penguin Books.

Korthals Altes, W. L. 1991. Changing Economy of Indonesia, Vol. I 2a, General Trade Statistics I 822-1940. Amsterdam: Royal Tropical Institute.

Korthals Altes, W. L. 1994. Changing Economy of Indonesia, Vol. 15, Non-rice Prices. Amsterdam: Royal Tropical Institute.

Kuitenbrouwer, Maarten. 1991. The Netherlands and the Rise of Modern Imperialism: Colonies and Foreign Policy I870-I9O2. New York and Oxford: Berg.

Leurence, F. 1925. 'Etude statistique sur le développement économique de L'Indochine', Bulletin Economique de l'Indochine, pp. 127-61.

Marseille, Jacques. 1984. Empire colonial et capitalisme français: histoire d'un divorce. Paris: Albin Michel.

Meredith, David. 1996. 'British Trade Diversion Policy and the "Colonial Issue" in the 1930s', Journal of European Economic History, Vol. 25(1), Spring, pp. 33-66. 
Mitchell, B. R. 1982. International Historical Statistics: Africa and Asia. Basingstoke: Macmillan.

Mitchell, Kate L. 1942. Industrialisation of the Western Pacific, Part III, An Economic Survey of the Pacific Area. New York: Institute of Pacific Relations.

National Planning Commission. 1960. A Study of the Social and Economic History of Burma (British Burma), Part VIII British Burma from the Rebellion of I93 I to the Japanese Invasion of I94I. Rangoon: National Planning Commission, Ministry of National Planning.

Norlund, Irene. 1991. 'The French Empire, The Colonial State in Vietnam and Economic Policy', Australian Economic History Review, Vol. XXXI, (1), March, pp. $72-89$.

Norlund, Irene. 2000. 'Rice and the Colonial Lobby: The Economic Crisis in French Indo-China in the 1920 s and the 1930s' in Peter Boomgaard and Ian Brown (eds), Weathering the Storm: The Economies of Southeast Asia in the I93os Depression. Leiden: KITLV Press and Singapore: Institute of Southeast Asian Studies.

Persell, Stuart Michael. 1983. The French Colonial Lobby, I889-1938. Stanford: Hoover Institution Press.

Philippine Economic Association. 1934. Economic Problems of the Philippines. Manila: Bureau of Printing.

Rahm, Henry A. 1952. 'L'Action de la France en Indochine', Bulletin Economique de L'Indochine, Vol. 55 (1), pp. 10-109.

Schweitzer, Thomas A. 1971. The French Colonialist Lobby in the I93o's: The Economic Foundation of Imperialism. PhD Dissertation, University of Wisconsin.

Schwulst, E. B. 1931. 'Report on the Budget and Financial Policies of French Indo-China, Siam, Federated Malay States and the Netherlands East Indies' in Report of the Governor General of the Philippine Islands I93I. Washington: US War Department.

Service de la statistique générale (1947), Annuaire Statistique de l'Indochine, I943-46. Hanoi: Imprimerie d'Extrême-Orient.

Shepherd, Jack. 1941. Industry in South East Asia. New York: Institute of Pacific Relations.

Sompop Manarungsan. 1989. Economic Development of Thailand, I850-1950. PhD Dissertation, State University of Gröningen.

Sompop Manarungsan. 2000. 'The Rice Economy of Thailand in the 1930s Depression' in Peter Boomgaard and Ian Brown (eds). Weathering the Storm: The Economies of Southeast Asia in the I93os Depression. Leiden: KITLV Press and Singapore: Institute of Southeast Asian Studies.

Swan, William L. 1988. 'Aspects of Japan's Prewar Economic Relations with Thailand' in Chaiwat Khamchoo and E. Bruce Reynolds (eds). Thai-Japanese Relations in Historical Perspective. Bangkok: Chulalongkorn University Institute of Asian Studies, Monograph Number 41.

Takada, Yoko. 200o. 'Historical Agrarian Economy of Cochin-China' in Jean-Pascal Bassino, Jean-Dominique Giacometti and K. Odaka (eds). Quantitative Economic History of Vietnam I900-1990. Tokyo: Hitotsubashi University, Institute of Economic Research.

Touzet, André. 1934. L’Economie Indochinoise et la grande crise universelle. Paris: Marcel Giard.

Touzet, André. 1939. Le Régime Monétaire Indochinois. Paris: Librairie du Recueil Sirey.

United States Tariff Commission. 1937. United States-Philippine Trade with Special Reference to the Philippine Independence Act and Other Recent Legislation: Second Series: Report i 18 . Washington: Government Printing Office. 
Van der Eng, Pierre. 1992. 'The Real Domestic Product of Indonesia, 1880-1989', Explorations in Economic History, Vol. 29, pp. 343-73.

Van der Eng, Pierre. 1993. 'The Silver Standard and Asia's Integration into the World Economy', Working Papers in Economic History, Number I75, Canberra: Australian National University.

Van Laanen, J. T. M. 1980. Changing Economy in Indonesia, Volume 6: Money and Banking, I 8I6-I940. The Hague: Martinus Nijhoff.

Vichitvong na Pombhejara. 1978. 'Thailand's Monetary Development in the 1930s' in Vichitvong na Pombhejara (ed.). Readings in Thailand's Political Economy. Bangkok: Bangkok Printing Enterpries. 